\title{
From Alienation to Solidarity: Educational Perspectives and Possibilities in Brazil and the UK
}

\author{
José Ernandi MENDES | oRCID: oooo-ooo1-5253-1565 \\ Universidade Estadual do Ceará [UECE], Fortaleza, Ceará, Brazil \\ ernandi.mendes@uece.br
}

Elenice Rabelo COSTA | orcID: oooo-ooo3-1648-o881

Basic Education Teacher, Brazil

elenicerabelocosta@gmail.com

Spyros THEMELIS | oRCID: oooo-ooo2-6681-4643

Associate professor, University of East Anglia (UEA), Norwich, UK

Corresponding author

s.themelis@uea.ac.uk

Sandra M. GADELHA DE CARVALHO | ORCID: oooo-Ooo2-0759-2788
Adjunct Professor, Universidade Estadual do Ceará [UECE], Fortaleza,
Ceará, Brazil
sandra.gadelha@uece.br

\begin{abstract}
In this paper, we examine how alienation plays out in conditions of advanced neoliberalisation in education. We discuss two examples which exemplify the depth and extent of alienation. First the attacks on critical thinking in education that have been spearheaded by the 'School without [political] parties' ['Escola sem Partido'] project in Brazil. Second, the mental health crisis that is rampant among staff and students in the UK higher education. Drawing on Freire, we explore how the organization of alienation' can fuel acts of resistance and praxis which can help us reclaim education and society from the forces of the market. The examples we draw on in relation to Brazil and the UK have not yet become mainstream strategies, especially internationally, that can sustain a resistance movement in education, but they form successful local, in some cases national even, strategies that seem to be able to open
\end{abstract}


new possibilities which can eventually help us find creative and effective ways to make the organisation of alienation the project for Being More that Freire envisaged.

\section{Keywords}

alienation - Freire - solidarity - education - Brazil - UK - social movements - praxis Marx

\section{Introduction}

While Marx talks about alienation in the material world as directly linked to commodity production in capitalist society, alienation in Freire (1987) takes the meaning of oppression and is directly related to ideological domination and the processes produced in the consciousness of the oppressed. The latter are alienated for being subjected to hegemonic discourses that make it impossible for them to comprehend reality and pursue their dreams (Freire, 1987). In Pedagogy of the Oppressed, the concept of alienation transits between the material and the spiritual, which creates a tension between the philosophy of praxis and phenomenology, between Marxism and Christian idealism. Freire (1987) deals with this tension by exploring alienation in society and education. In this paper, we draw on two diverse contexts, Brazil and the UK, in order to examine how alienation plays out in conditions of advanced neoliberalisation in education. First, we discuss some policy changes such as the controversial Brazilian 'School without [political] parties' ('Escola sem Partido') project that was designed in order to promulgate the abolition of (critical) social science subjects in universities, such as Sociology, Philosophy and Political Science. Second, we explore the mental health crisis that is rampant among British university staff and students. Both cases are instantiations of a deepening of alienation in education and society. Our account draws on Freirean theory in order to highlight the rootedness of alienation in neoliberal society and education. Although alienation in each context takes different characteristics and it is linked to varied historical, socio-economic and political processes, we argue that neoliberalism has deepened and further entrenched alienation in both Brazilian and British society and education. The concept of alienation is very important to broaden the reading of the current reality in Brazil and the UK, because it allows the observation of different aspects of reality and points to educational resistance actions. 
In this paper, we discuss alienation through the prism of education. First, we explore some recent policy changes in the Brazilian education system, which have resulted in an ever-increasing alienation among stakeholders and especially among those fighting for its reform along democratic, equal, decolonial and more just lines. Second, we explore alienation in the UK context through the deepening mental health crisis in higher education ( $\mathrm{HE})$. We argue that the contradictions inherent in global capitalism, despite any local variations, have intensified the prevalence of alienation. We conclude by discussing alienation as the organizational springboard that can lead to political praxis in education. We explore the latter's potential not only in resisting the neoliberal state of affairs but also in creating synergies, solidarities and the critical mass for liberating humans from alienation and humanizing society.

\section{Contextualising Alienation in Brazilian and UK Education}

Brazil started the year 2019 plunged into multiple crises. First, a political crisis. The country's president, Jair Bolsonaro, won the election with the backing of the media, financial markets, agribusiness and neo-Pentecostal Evangelical churches, such as Universal Church of the Kingdom of God. Many claim that he was only able to win thanks to the arrest and imprisonment of Luis Inácio Lula da Silva (aka Lula), the center-left candidate and former president, a few months before the 2018-election. Second, a judicial crisis. The role of the judiciary in sentencing Lula, raised suspicions about the independence of the judiciary. Third, a human rights crisis. Since his election, Bolsonaro's Brazil has regressed on its human rights record. Organised attacks on the working class as well as on activists, such as indigenous, black, women, LGBTQI+ ${ }^{1}$ and environmentalists are commonplace. Fourth, an educational crisis. The attack on education takes place on two fronts: on the one hand, by strengthening and deepening neoliberalism. Financial cuts are imposed on public education and especially on universities with the pretext of privatization, making it impossible for institutions to fulfil their roles of providing the country with technological autonomy and allowing underprivileged sectors of the population to access HE. On the other hand, since Lula improved access and opportunities to

\footnotetext{
1 LGBTQI +: This abbreviation is divided into two parts. The first, LGB, concerns the sexual orientation of the individual. The second, TQI +, concerns gender. L: Lesbian; G: gay men; B: Bisexuals; T: Transsexuals, transvestites and transgender people; Q: Queer, ie. people who do not identify with the patterns of hetero-normativity imposed by society and transit between "genders" without necessarily agreeing with such labels; I: Intersexuals, formerly called hermaphrodites, or people who cannot be clearly defined in male or female. +: describes all other letters in LGBTT2QQIAAP, such as "A" for asexuality and "P" for pansexuality.
} 
lower income students and his main support emerged from Universities and intellectuals, the present government tries to "de-politicize" educational institutions, abolish diversity of thinking and establish a single 'truth' by weeding out epistemological pluralism. It does so by launching a strong ideological offensive against science in general and critical knowledge in particular, discrediting pedagogy and critical knowledge and accusing schools and universities of harbouring indoctrination and partisan practices (Cássio, 2018). As part of this campaign, a reactionary movement called "School Without Parties" was created by the far-right and with the support of neo-Pentecostal church, which denounces criticality in education. ${ }^{2}$ Similar to the "No to indoctrination" movement promoted by the far-right in the USA, a radical regressive campaign is ongoing that aims to restrict thinking and forge an anti-intellectual 'common sense' in education.

More than twenty years after the death of Paulo Freire, ${ }^{3}$ his ideas on education as a "practice of freedom" have become the focus of systematic attacks by representatives of the far-right. In one of the biggest demonstrations organised by the Right in favor of the impeachment of President Dilma Rousseff, ${ }^{4}$ in 2015, a large banner read: "Enough Marxist indoctrination. Enough Paulo Freire". These attacks on Paulo Freire represent an organised offensive against all critical and emancipatory practices of teachers in general, but also of activists and especially those on the Left. The far-right targets all those who fight for social justice; the latter are immediately branded as "Petistas"5 and/or communists as part of a campaign to tarnish their struggle. The first traces of critique of Freire's ideas can be found in the 196os and 1970s. The military who carried out the coup in 1964 considered Freire as a subversive element responsible for enunciating an education for critical consciousness and social transformation. Others saw him as a developmental nationalist, distant from

2 The rise of the far-right is part of a conservative wave happening in other South American countries such as Bolivia, Paraguay, and Uruguay (Oliveira, 2019). In others countries in the world, like EEUU, UK and Hungry, a similar process takes place.

3 Paulo Reglus Neves Freire was born in 1921 in Recife, Brazil, in the State of Pernambuco. He is one of the most important representatives of critical pedagogy and his ideas have shaped the movement of Critical Pedagogy. In 2012, he was declared the godfather of Brazilian Education.

4 Dilma Rousseff (Workers Party), was impeached in 2016, in her second administration. The impeachment was performed by far-right political forces in Brazil.

5 "Petistas" are people affiliated to the Workers Party (РT). The media and spokespersons of the right have propagated for years the false idea that corruption in Brazil was the responsibility solely of the Workers Party, while the most corrupt people belong to right-wing parties with which the PT was associated, and not to the PT itself. In right-wing discourses, the term 'Petistas' carries a pejorative sense and designates everybody on the Left who is in favor of human rights, regardless of the party or social movement to which he or she belongs and this includes political parties such as the PSOL (Socialist and Freedom Party) and the РСв (Brazilian Communist Party), and social movements such as the MST (Landless Workers Movement) and MTST (Homeless Workers Movement). 
the materialist view of reality (Paiva, 1980). However, the current campaign is different because it is part of a wider movement to redistribute resources away from the disadvantaged, to privatise even further the Brazilian state and to subjugate education to the ruling class. In a nutshell, the current anti-Freire campaign is part of the neoliberal strategy to occupy power and deepen the neoliberalization of Brazilian society and education. As the contradictions within the Brazilian society and education deepen, alienation is more pronounced and heightened than ever before.

In relation to the UK, alienation has its roots in the slow remaking of the UK political economy that Margaret Thatcher introduced in the 1970s and subsequent governments extended, embedded and deepened. Thatcher's famous adage 'there is no such thing as society. There are individual men and women, and there are families', (Steele, 20o9) popularised, at least in the English speaking world, the teachings of Friedrich Hayek, who gave theoretical ballast to neoliberalism. The repercussions of the hollowing out of society from collectivities and the apotheosis of the atomised individual underpin the mental health crisis currently evident in the UK and will be discussed later.

In education, Thatcher paved the way for the establishment of quasi-markets and the erosion of the public sector in running education, from early years to HE. Subsequently, a remarkable continuity prevailed, which subordinated education, and especially higher education, to neoliberalism and the forces of the markets that this shift entails. Within four decades, students were turned into customers and university degrees into expensive commodities: tuition fees rose from $£ 1$ 1ooo in 1998 when they were introduced to over £9ooo in 2010, making the UK HE system one of the most expensive in the world. The introduction of tuition fees and the concomitant reduction in state funding helped create a new moral economy (Ball, 2006) in a context of a rapidly transformed political economy. New expectations, potentialities and technologies of control and management emerged that made academia a locus of intense marketization but also conflict. In this context, academic labour has sustained a series of injuries, such as casualization of its staff, a deterioration in their working conditions, reduction in salaries, decrease in the value of their pensions, gender pay gap and so on.

The casualization of academic labour, for example, is now considered 'a significant problem in UK HE, being a fundamental attack on the human dignity on those caught up in it' (Megoran and Mason, 2020, p. 3). Rendering UK HE into such a prime site of exploitation and alienated labor, ${ }^{6}$

6 Higher Education Statistics Agency (HESA), 2017/18, shows that nearly $67 \%$ of researchers and $49 \%$ of 'teaching-only' staff in the sector are on fixed-term contracts. What is more, $42 \%$ of all teachingonly staff are on hourly paid contracts, a large number $(6,500)$ of academic staff are on zero-hours contracts and an even larger amount (70,000) are characterised as 'atypical' staff. 
is the outcome of a concerted effort, 'a business model on which universities depend.' (Megoran and Mason, 2020). A study by Kinman and Wray (2013) showed that university staff are more stressed than the average British worker and that the problem has got worse in recent years. Likewise, academic workers blame their working conditions for their mental health issues and illnesses and feel isolated and concerned about a bullying culture, job insecurity and a culture of long working hours (Shaw, 2014). More recently, a research study found that 'casualised academic labour is fundamentally dehumanising in that it renders staff invisible and vulnerable, curtails their agency and freedom, and prevents them from rendering a long-term narrative of their career that can provide meaning to their lives. They are treated as second-class academics.' (Megoran and Mason, 2020). It is expected that the covid-19 pandemic will stretch even further national budgets in the UK and almost certainly lead to higher casualization, redundancies and mental health issues among academic workers.

Regarding HE students in the UK, there is plenty of evidence suggesting that mental health levels among them have significantly worsened over the last few decades. According to a survey by the Mental Health Foundation (2017, p. 6) 'our collective mental health is deteriorating [...and...] young adults report this at a higher level, despite having had fewer years in their lives to experience this.' Between 1993 and 2014, the percentage of over 16-years-old adults in the UK reporting a common mental health disorder increased from 14 per cent to nearly 18 per cent. At the same time, student debt levels have increased to unprecedented levels. While some authors are cautious to draw any association between debt and mental health issues (Richardson et al., 2013b), several studies have found a direct connection between them (McCloud and Bann, 2019; Andrews \& Wilding, 2004; Richardson et al., 2013a; Fitch et al., 2011). Furthermore, in recent years, several studies linked student loan debt with poorer health among students (e.g. Cooke, Barkham, Audin, Bradley, \& Davy, 2004; Morra, Regehr, \& Ginsburg, 2008; Ross, Cleland, \& Macleod, 2006; Walsemann, Gee, \& Gentile, 2015). All these studies that reported such a link found that 'student loan debt is positively associated with incidence of financial distress' (de Gayardon, 2018, p. 34), such as financial struggle (Baum \& O'Malley, 2003; Dugan \& Kafka, 2014) having experienced bank overdrafts, bankruptcy and food insecurity (Despard et al., 2016; Gicheva \& Thompson, 2015) and so on.

Given all the above, Freire's ideas are important and necessary in trying to understand the formative processes that take place in conflicting social relations; it is a challenge, as well, for all who associate education with freedom and human emancipation. 


\section{Alienation in Society and Education: from Reality to Utopia}

Freire demonstrated that social reality is not a given, but has its own dynamics: it is a product of historical, economic, political, social and cultural determinants. Furthermore, his understanding of society stems from the two dimensions that accompanied him as a humanistic theorist-educator: what is known and what is felt, in concrete social relations. In two historical times, he expressed his understanding by means of the real - what is seen, felt and studied, and of the ideal - what is dreamed and desired. The author aimed at deepening the relationship between theory and practice; for him, the latter was first reference and main motivation for the production of knowledge, because he believed that reality had to be known to be transformed. The understanding of society is revealed when one denounces existing social conditions and announces a utopian sociability. Freire was a radical humanist defender of social justice who, in this movement of concrete thought, conveyed frequent outbursts of indignation. As will become apparent in the next section, this application of Freire's approach finds parallels in Brazil and the UK.

This utopian possibility is afforded by the concept of alienation, which transits between the material and the spiritual, between the perspectives of the philosophy of praxis and phenomenology, between Marxism and Christian idealism. Freire (1987) incorporates this tension by exploring the alienation which exists in society and education, as concepts and real categories. When alienation is deepened in Freire's understanding of society, a dialogue with Marxian thought unfolds.

Although Freire shares the belief that work is the foundation of social beings, he reminds us that work under capitalism is also responsible for alienating people (Streck, Redin and Zitkoski, 2017). In the capitalist mode of production, which is based on manufacturing goods, the worker is forced to sell their labor force and is expropriated from the means of production, the knowledge acquired in the labor process and the product itself (Marx, 1964). That's why the worker is expropriated from his/her own humanity as soon as his/her labor force is alienated and equated with a commodity, because labor ceases to be the free activity used to provide for the workers' material and spiritual existence:

Alienating the worker from his [sic] product means not only that work becomes an object with an [assumed] external existence, but independently exists outside and alien to him and becomes an autonomous power in opposition to him; that the life he gave to the object becomes a hostile and antagonistic force (Marx, 1964, p. 160). 
Alienation is materialized in the social division of productive labor, that is to say in the effective separation between those who control work and those who actually perform it. The worker is committed to guaranteeing his/hers vital needs: eating, dressing, drinking, etc., and has to refuse activities in which he/ she no longer recognizes himself.

According to Marx (1964) the alienation process of the value of work in capitalist production takes place to the extent that the worker does not obtain the value of the labor object he/she produces. This value is expropriated by those who have the means of production, who guarantee for themselves the real and concrete values of everything the worker produces with his/her labor. The capitalist mode of production builds a new subjectivity for the human being who lives from work, making him/her a productive piece in the process of wealth accumulation, a person who does not recognize himself/herself as a producer of the wealth he/she produces. A prime example of the function of alienation is through the rampant casualization of UK HE workforce and its deleterious effects on its incumbents' mental health condition. HE workers are dependent on their employer to cover their basic needs, such as the ones described above. However, the latter treats their labor as a source of income loss for the organization that has to be minimized. In dialogue with Marx's ideas, Freire aptly put it as follows:

The realization of men as men [sic] is therefore in the realization of this world. Thus, if your being in the labor world is a being in total dependence, in insecurity, in permanent threat, as long as your work is not yours, you cannot be fulfilled. Non-free labor is no longer a work of your person, but an effective means of your "reification" (Freire, 1987, p.142).

Alienation is effective in the submission to the economic, political and legal structure, as well as in the subjugation of the worker to existing working conditions and the denial of his/her rights. It materializes in the construction of common sense through the ideology conveyed by institutions, such as HE, in order to forge people's conformism and "dehumanization" in the face of the "unjust social order". This alienation manifests itself in the oppressed who inhabit the consciousness of the oppressor and who in:

"...their alienation want, at all costs, to be like the oppressor. Imitate him. Follow him. This is especially true of the oppressed 'middle class' which yearns to be equal to the 'illustrious man' of the so-called 'upper class'. (Freire, 1987, p.49) 
While Marx e Engels (2009) talks about alienation in the material world as directly linked to the process of commodity production in capitalist society, alienation in Freire (1987) has a more general meaning that involves oppression in the context of exploitation, and is directly related to ideological domination and the process produced in the consciousness of the oppressed. The latter are alienated for being surrounded by hegemonic discourses that make it impossible for them to comprehend reality. Instead, they pursue illusions, such as full employment and upward social mobility (Freire, 1987). The massification of higher education in the developed world is a vehicle through which these illusions are pursued. In Brazil and the $\mathrm{UK}$, this is evidenced by the widening participation policies that have been in place in the last 20 years or so, in order to help people from disadvantaged backgrounds enter HE. Especially in the UK, the widening of participation has intensified the mental health crisis experienced by students from such backgrounds as they struggle to make ends meet (see Section 2) and adjust to an environment that is alien to their culture, such as HE. The State and its institutions are so organized as to ensure the material reproduction of capital as well as the social reproduction of symbolic order through repressive, formative and ideological institutions, such as education. This is why alienation, despite being objectively an expression of capitalist production, is also a descriptive term of the discursive practices of the ruling class. Such practices and attendant discourses, such as widening participation in HE, get "lodged" in the consciousness of the oppressed and they contribute to generalization of a common sense. Although systemic alienation dehumanizes everyone, the working class are particularly affected: "The more politically immature they are (be they rural or urban), the more easily they can be manipulated by the ruling elites who do not want their power to be exhausted" (Freire, 1987, p.144).

Freire warned of the logic of the "ruling elites" or "ruling classes" who do everything to preserve alienation and maintain the status quo: "Through manipulation, the ruling elites try to conform the popular masses to their objectives."(Freire, 1987, p.144). The "ruling classes" will do everything to subjugate the "dominated masses" to the existing social structure.

Freire was angry about the injustices and inequalities in capitalist societies as he saw their dehumanizing role in the formation of individuals. Furthermore, he perceived mainstream education as an expression of this dehumanization. Freire (1987) understood that the oppressed were those who experience a dehumanizing relationship in education, in relation both to the pedagogical proposal and the knowledge transmitted, and who are destined to a subordinate 
position in society. In today's terms, these would be the victims of Bolsonaro's attacks on free and public education in Brazil as well as staff and students in UK HE whose mental health is affected because of their participation in it. Intriguingly, the oppressed feel and act in the world in a variety of oppressive relations, including the exploitation they suffer either through offering their labor or as students in HE.

For the relations between education and alienation are condensed into an ideological and political dispute between two antagonistic projects within society: one in favor of reproducing capitalist society and the other in favor of replacing it with an egalitarian one. In an alienated society, there is a constant tension of the oppressed and exploited for their humanization, since they are frustrated by dehumanization.

The alienating educational practice is based on a reductionist view of reality, in which subjects 'mythify' the order of things and fail to perceive the essence of social phenomena. This fatalistic worldview inhibits the self-recognition of individuals as historical beings, critics and artisans of social transformation. When alienation prevails in social and educational relations, as is the case in the current UK HE system with its high and rising levels of mental health problems, they force individuals to be passive. The contradictions inherent in the capitalist system, however, impel antagonistic subjects to an inevitable conflict, since they impose on the working class and the oppressed in general the need to discuss and understand their condition, to face the challenges and to build unalienated practices that can lead to their liberation. As we discuss in this section, such practices have been devised both in Brazil and the UK with varying degrees of success.

Freire realizes that this is the struggle of all the oppressed: "Unified and organized, however, they will turn their weakness into a transformative force with which they can recreate the world and make it more human" (Freire, 1987, p.142). The revolutionary praxis that occurs within class society is a humanizing and unalienated process, because oppressed subjects forge themselves as historical Subjects. Freire stated some elements of his broad understanding of education, which are associated with a praxis against all oppression. By doing so, he associated alienation/disalienation with alienated/free labor:

The struggle for humanization, free labor, disalienation and the affirmation of men as persons, as "beings for themselves," would have no meaning. It only does have one because dehumanization, even if a concrete fact in history, is not a given destiny, but the result of an unjust "order" that generates the violence of oppressors and generates the others, the lesser being (Freire, 1987, p.30). 
In Brazil, the dehumanisation supported by Bolsonaro's government aims to decrease educators' autonomy in schools and universities and eliminate school subjects such as Philosophy, Arts and Sociology. Educators struggle against this project through a political praxis that involves public protests in front of the Congress, the Governor's Palace, in the streets, in seminars and by alerting people through digital campaigns.

Only through such a political praxis of "revolutionary transformation" that corroborates the process of social liberation can there be any historical commitment (Sousa Júnior, 2010). However, this is a complex and difficult task, since the ideological strings of alienation that intertwine throughout the social fabric need to be broken. This is only possible through the construction of an emancipatory collective consciousness of the oppressed and exploited, and for this a long educational and formative process has to take place. At the core of this transformation have to be 'the very structures of white supremacist capitalist patriarchy by means of a pedagogical praxis guided by the revolutionary knowledges of historical materialism. In so doing, questions of patriarchal and sexist ideology are connected to their material origins - of social labor - that emphasize the relations between the sexes and how the distribution of labor in capitalist economies have generated the alienating conditions in which men and women relate to themselves and to one another (Ebert \& Zavarzadeh, 2008, in McLaren, 2010, p. 1).

In this sense, education plays an important role in the construction of another society which is founded on the dialogue between subjects who stand next to each other and face each other. It is based on respect for culture, popular knowledge and the diversity of subjects, while preparing individuals, collectivities and society for a life without oppression and exploitation. The practice of educators as historical subjects, such as those resisting the project 'Schools without Parties', shapes a humanized society as long as it is founded on the incessant pursuit of humanization. For Freire, humanism and humanization stem from revolutionary educational practices that transcend any oppressive reality and oppression, such as the one faced by millions of education workers and students in modern-day Brazil.

A different instantiation of educational praxis to overcome alienation is offered through the 2019 and 2020 strikes that workers in UK HE institutions called against their employers. Those strikes were met with active support by individual students and student unions across the country and showed what is possible when political praxis is used to overcome the contradictions of class society, exploitation and oppression, as Freire discussed (see Section 3). Building a society without dehumanization is based on subjects who are critically inserted and historically committed to the transformation of reality, who create and recreate knowledge, practices and social relations. 
The idea of a problematizing and liberating education in Freire (1987) is linked to the construction of a free society with autonomous relations, in which human beings are together and learn how to overcome oppression. A liberating education is transmitted inside the oppressive society; it disputes banking education and the social relations of oppression. For example, during the strikes in UK HE in 202O, the alienated staff and students came together to explore alternative grammars of socialization and suggest new social relations. Through teach-ins, joint demonstrations, cultural events, talks and osmosis in the process of resistance, they discovered that they have common interests which they can develop through social and educational practices. They realized possibilities for a future society by fighting and educating against labor alienation which is reflected throughout the entire social life, within the material and spiritual world as well as HE practices.

Therefore, when Freire defended those who want to be more and are prevented from being, he spoke about the importance of unifying the working class and about the perception that this social group is composed by many collective subjects who all have their specific demands. They are: black, indigenous, women, LGBTQI +, youth and peasants. They are the ones currently mostly targeted by the Brazilian government and those whose dreams are compromised by the deepening of neoliberalism. They are the ones who resisted the "School Without Parties" attacks, through the use of traditional and social media, as well as by organizing seminars, publics classes, and one of the biggest public protests, in 2019, called "Education Tsunami". The latter was a mass public event organized in support of freedom of expression and the suspension of plans to cut central government funding for education.

What is more, Freire argued that alienation must be fought in all spheres of society and this is the task of educators and fighters. The fight against alienation of conscience goes hand in hand with respect for human diversity and identities, which are so rich in social experiences (Arroyo, 2013). Even formal education can play an indispensable role in the critical development of individuals towards their own human and social emancipation and the fight against alienation. In the Brazilian context, some educators promote political poetry evenings in schools and universities against the "School Without Parties" project and in favor of public education that can promote humanization.

The latter lies in the ability of subjects to produce themselves in reflection and history and transform reality (Freire, 1987), for liberation of the oppressed only makes sense when it implies the humanization of the 
individual. Men and women as subjects of their educational practice and of their own autonomy are free to dialogue about the world and transform it. They constantly seek possibilities to be more: "This search, however, is only justified to the extent that it means Being More, i.e. the humanization of men [sic]" (Freire, 1987, p.74).

If human praxis is conditioned on liberation, the historical construction of sociability without oppression, then it is the result of improving human consciousness about reality, of critical and reflective thinking, and of the commitment to Being More for society as a whole. As Freire (1987, p.53) highlighted, liberation of the oppressed is liberation of humans, not of "things". Therefore, it is not self-liberation - no one liberates their own self- neither individually. Liberation is essentially a collective act. That is why it is necessary to create new educational possibilities for the working class and diverse social movements, such as the ones that have been created in response to the "School Without Parties" attacks in Brazil and as a result of the neoliberal assault in UK HE. As we showed above, the essence of education goes beyond schooling as it is inherent in all social practices. As soon as the oppressed understand reality and are aware of it, they engage in a process of self-formation, in a dialogue to exchange experiences with leaders of revolutionary social movements and trade unions.

Subjects educate themselves in their formative, self-forming and self-organizing experiences. Struggle educates the consciousness, both of those who characterize themselves as mass and those who characterize themselves as their leaders:

That's the way it is: the education of revolutionary leaders turns into co-intentionality. Educator and educated, leaders and masses, co-intentionally shape reality. They find themselves in a task in which both are subjects in the act, and they not only unveil and critically know it, but also recreate this knowledge (Freire, 1987, p.56).

However, the critical and emancipatory formation of individuals is not a linear nor a simple process. Arroyo (2013) points out that a person's learning process depends on a series of social, political and economic tensions that he or she faces in society. Torres (2014) shows that the integrated perspective of Freire's thinking about education goes beyond school walls. This means that there is a need to focus on praxis and its contribution to an unabridged formation of a person to gain a critical and emancipatory perspective. 
According to Freire, an education for the consciousness of the masses must be elaborated out of an essentially collective perspective. Educators and learners must feel like equal subjects, if inspired by the same project of sociability and they are capable of liberating themselves together. With shared solidarity they are together as subjects who can recreate knowledge, and they assume for themselves the responsibility of transforming the reality in which they are immersed:

When they reach this knowledge of reality in reflection and common action, they discover that they themselves are their own permanent remakers. Thus, the presence of the oppressed in the quest for liberation is not pseudo-participation, but what it really should be: engagement (Freire, $\left.1987, \mathrm{p} .5^{6}\right)$.

By becoming aware of individual and collective liberation, they understand that the transformation process of reality is permanent and that the process of educating the human being will never finish. Subjects involved in dialectical practice understand that they learn more every day in social struggles, social relations and in dialogues with formal and non-formal knowledge. Freire (2014) showed us that being engaged and immersed in struggles gives rise to new Beings, whose conscience opens to unveil the world and who find sense and meaning for their actions. When moved by the feeling of solidarity, individuals begin to perceive reality in a more complex way, and commit themselves to transform it thanks to their self-formation.

\section{5 \\ Conclusion}

The concepts of society and education, as established by Freire, are connected both when denouncing the oppressive class society and dehumanizing banking education, and when announcing a society without oppression but with liberating education.

Freire, however, never accommodated to the given reality, and his opposition to social oppression reverberated in sharp criticism of the educational system. In this context, the humanist Freire was rather motivated to conceive pedagogical practices which help to cope with and overcome the relations he considered to be oppressive. His place in the world, the ability to feel the pain of the oppressed - coupled with his utopia and willingness to transform - led him to produce a pedagogy that stands beside the oppressed, a pedagogy of the oppressed, which problematizes reality and contributes to put an end to alienation. 
Moreover, Freire argued that education is one of the tools to develop society. Not any education, though. His pedagogical concept questions the sociability of capitalism and the pedagogical proposal of the existing educational system, and points to educational practices which help to liberate the oppressed, improve their consciousness, commitment and willingness to transform reality.

Educators do not feel alienated when they know they can transform education into something positive. When their passivity is superseded by their active engagement to overturn the conditions of their alienation 'the working class confronts its own labor as capital, as a hostile force, as an enemy - this is the point of departure not only for the antagonism, but also for the organization of the antagonism. If the alienation of the worker has any meaning, it is a revolutionary one. The organization of alienation $[\ldots]$, hence, the immense task of working-class organization is to overcome alienation' (Tronti, 1966).

In current day Brazil, the struggle to overcome alienation is born in the opposition to authoritarian education, in the struggle to educate everyone and especially the most disadvantaged as well as in the fight to respect all cultures and backgrounds. In the UK, the revolutionary meaning of alienation is found in the HE strikes that unions have waged against alienation of academic workers. Struggling against alienation in Brazil and the UK is part of the struggle to humanize society and education. While the character of each struggle might very in form, their content and aim are the same.

For neoliberal globalisation has succeeded in dehumanising society, but it is through humanist education that it is resisted and superseded. Borrowing strategies to manage the economy among nation states and intensificating the race to the top that neoliberal education facilitates, seem to have had an unforeseen consequence. That of raising awareness about the inherent flaws of globalisation and capitalism more broadly. The movements in Brazil and the UK echo similar ones, such as the occupy movement or the squares movement, even to an extent extinction rebellion and other movements that challenge the capitalist orthodoxy or elements of it. These movements seek to challenge the conditions that generate such alienation or, in some cases, the entire capitalist system of production.

The organisation of alienation as a project of epistemological renewal and pluralism, as an exit to current social relations, needs to be approached as a strategy to create alternative social relations, void of oppression, exploitation and alienation. In so doing, Brazilian and UK movements in and out of education, point to three strategies. First, to the creation of an ongoing dialogue to communicate with the oppressed the need to engage in counter-hegemonic movements and strategies. Second, building unity within these movements. 
Third, juxtaposing 'global solidarity' to 'globalisation' and being committed to learn with and from each other. These strategies are drawn from the experiences of specific social movements and they have been applied or explored to some extent in Brazil and/or the UK.

In the challenges posed by the current reality and also in the patriarchal/ capitalist, as well as colonial/neoliberal world system, Freire's conception of education and society becomes more crucial than ever before as the foundation of an educational praxis which focuses on social emancipation.

The examples we draw on in relation to Brazil and the UK have not yet become mainstream strategies, especially internationally, that can sustain a resistance movement in education with which to fight against alienation and reclaim education and society from the forces of the market. However, they form successful local, in some cases national even, strategies that seem to be able to open new possibilities which can eventually help us find creative and effective ways to make the organitazion of alienation the project for Being More that Freire envisaged.

\section{Acknowledgements}

We would like to thank two anonymous reviewers for their useful comments to an earlier version of this paper. Any errors and omissions are completely the authors' responsibility.

\section{References}

Andrews, B., \& Wilding J.M. (2004, November). The relation of depression and anxiety to life-stress and achievement in students. British journal of psychology. 95 pp. 509521. doi: 10.1348/00o7126042369802.

Arroyo, Miguel G. (2013). Currículo, território em disputa (5th ed.). Petrópolis, RJ: Vozes. Ball, S. J. (2006) Education Policy and Social Class: The Selected Works of Stephen J. Ball. London: Routledge.

Baum, S., \& O'Malley, M. (2003). College on credit: How borrowers perceive their education debt. Journal of Student Financial Aid. 33(3), 1.

Cássio, F. (org.) (2018). Educação contra barbárie: por escolas democráticas e pela liberdade de ensinar. São Paulo,SP: Boitempo.

Cooke, R., Barkham, M., Audin, K., Bradley, M., \& Davy, J. (2004). Student debt and its relation to student mental health. Journal of Further and Higher Education. 28(1) pp. 53-66. https://doi.org/10.1080/0309877032000161814. 
de Gayardon, A., Callender, C., Deane, K., \& DesJardins, S. L. (2018). Graduate indebtedness: its perceived effects on behavior and life choices. Centre for Global Higher Education working paper series. Retrieved September 20, 2020, from https:// www.researchcghe.org/perch/resources/publications/wp38.pdf.

Despard, M. R., Perantie, D., Taylor, S., Grinstein-Weiss, M., Friedline, T., \& Raghavan, R. (2016). Student debt and hardship: Evidence from a large sample of low- and moderate-income households. Children and Youth Services Review. 70 pp. 8-18. https://doi.org/10.1016/j.childyouth.2016.o9.oo1.

Dugan, A., \& Kafka, S. (August 7, 2014). Student debt linked to worse health and less wealth. Retrieved August 23, 2017, from http://www.gallup.com/poll/174317/studentdebt-linked-worse-health-lesswealth.aspx.

Fitch, C., Hamilton, S., Bassett, P., et al (2011). The relationship between personal debt and mental health: a systematic review. Mental Health Review Journal. 16(4), 153-166. https://doi.org/10.1108/13619321111202313. Retrieved September 20, 2020, from https://psycnet.apa.org/record/2012-03150-oo1.

Freire, P. (1987). Pedagogia do Oprimido (17th ed.). Rio de Janeiro: Paz e Terra.

Freire, P. (2014). Pedagogia da Esperança: um reencontro com a Pedagogia do Oprimido. São Paulo: Paz \& Terra.

Gicheva, D., \& Thompson, J. (2015). The effects of student loans on long-term household financial stability. In Hershbein B. J. \& Hollenbeck K. M. (Eds.). Student loans and the dynamics of debt. Kalamazoo, MI: W.E. Upjohn Institute for Employment Research. doi: 10.17848/9780880994873. Retrieved September 20, 2020, from http://edpolicy. umich.edu/files/gicheva-thompson-effects-student-loans.pdf.

Higher Education Statistics Agency (HESA). Higher Education Staff Statistics:UK, $2017 / 18$. Retrieved September 20, 2020, from https://www.hesa.ac.uk/news/24-01-2019/ sb253-higher-education-staff-statistics.

Kinman, G. \& Wray, S. (2013). Further Stress: A Survey of Stress and Wellbeing among Staff in Further Education. UCU. Retrieved September 20, 2020, from http://www. ucu.org.uk/media/pdf/3/o/FE_stress_report_July_2013.pdf.

Marx, K. (1964). Manuscritos econômicos filosóficos. Lisboa: Edições 70.

Marx, K., \& Engels, F. (2009). A ideologia alemã. São Paulo: Expressão Popular.

McCloud, T., \& Bann, D. (2019, August). Financial stress and mental health among higher education students in the UK up to 2018: rapid review of evidence. Journal of Epidemiological and Community Health. 73 pp. 977-984. doi: 10.1136/ jech-2019-212154.

McLaren, P. (2010). Revolutionary Critical Pedagogy. InterActions: UCLA Journal of Education and Information Studies. 6(2). Retrieved September 20, 2020, from https://escholarship.org/uc/item/7qj2b57o. 
Megoran, N., \& Mason, O. Second-Class Academic Citizens. Retrieved July 2, 2020, from https://www.ucu.org.uk/media/1o681/second_class_academic_citizens/pdf/ secondclassacademiccitizens.

Mental Health Foundation (2017) Surviving or thriving? The state of the UK's mental health. Retrieved September 20, 2020, from https://www.mentalhealth.org.uk/sites/ default/files/surviving-or-thriving-state-uk-mental-health.pdf.

Morra, D. J., Regehr, G., \& Ginsburg, S. (2008). Anticipated debt and financial stress in medical students. Medical Teacher. 30(3) pp. 313-315. https://doi. org/10.1080/0142159080195300o.

Oliveira, Felipe Antunes (2019). The rise of the Latin American far-right explained: dependency theory meets uneven and combined development. Globalizations. 16(7) pp. 1145-1164. doi: 10.1080/14747731.2019.1567977. Retrieved September 20, 2020 from https://www.tandfonline.com/doi/abs/10.108o/14747731.2019.1567977.

Paiva, V. (1980). Paulo Freire e o nacionalismo desenvolvimentista (1st ed., v.1). Rio de Janeiro: Civilização Brasileira.

Richardson, T., Elliott, P., Roberts, R. (2013). The relationship between personal unsecured debt and mental and physical health: a systematic review and meta-analysis. Clinical Psychology Review. 33 pp. 1148-1162. doi: 10.1016/j. cpr.2013.08.oog. Retrieved September 20, 2020, from https://www.researchgate. net/publication/257754299_The_relationship_between_personal_unsecured_debt_ and_mental_and_physical_health_A_systematic_review_and_meta-analysis.

Richardson, T., Elliott, P., Roberts, R. (2015). The impact of tuition fees amount on mental health over time in British students. Journal of Public Health. 37 pp. 412418. https://doi.org/10.1093/pubmed/fdvoo3. Retrieved September 20, 2020, from https://academic.oup.com/jpubhealth/article/37/3/412/236277o.

Ross, S., Cleland, J., \& Macleod, M. J. (2006). Stress, debt and undergraduate medical student performance. Medical Education. 4o(6) pp. 584-589. https://doi.org/10.111 $1 / j .1365-2929.2006 .02448$.

Shaw, C. (May 8, 2014). Overworked and isolated - work pressure fuels mental illness in academia. Guardian. Retrieved September, 20, 2020, from https:// www.theguardian.com/higher-education-network/blog/2014/may/o8/ work-pressure-fuels-academic-mental-illness-guardian-study-health.

Sousa Júnior, J. (2010). Marx e a crítica da educação: da expansão liberal-democrática à crise regressivo-destrutiva do capital. Aparecida, SP: Idéias \& Letras.

Steele, G.R. (2009). 'There is no such thing as society'. Institute of Economics Affairs (IEA). Retrieved September 20, 2020, from https://iea.org.uk/blog/ there-is-no-such-thing-as-society.

Streck, D. R., Redin, E., Zitkoski, J. J. (Orgs.). (2017). Dicionário Paulo Freire. Belo Horizonte: Autêntica Editora. 
Torres, C.A. (2014). Diálogo e práxis educativa - Uma leitura crítica de Paulo Freire. São Paulo: Edições Loyola.

Tronti(1966) refers to this reference in the list (see AQ11) which needs a date added, i.e. 1966: correct reference is: Tronti, M. (1966) The Struggle Against Labour. Radical America. 6(3) pp. 22-23

Walsemann, K. M., Gee, G. C., \& Gentile, D. (2015). Sick of our loans: Student borrowing and the mental health of young adults in the United States. Social Science \& Medicine. 124 pp. 85-93. https://doi.org/10.1016/j.socscimed.2014.11.027. Retrieved September 20, 2020, from https://pubmed.ncbi.nlm.nih.gov/25461865/. 